\title{
Science, a Metaphor of Nationalism: Acharya Prafulla Chandra Ray and Postcoloniality
}

\section{Biswanath Banerjee}

\begin{abstract}
The scientific and intellectual Renaissance of Bengal in the late nineteenth and early twentieth century had acted as a major force in the triumph of independence of India and its progress towards a modern civilization. In the history of this new scientific awakening Acharya Prafulla Chandra Ray (1861-1944) occupies a significant position who realized the importance of science as integral to nationalist consciousness and nation building. Ray envisioned science to be a common concern of all humankind which was to be integrated with the development of a public use of reason and the emergence of Indian Nationalism through the establishment of national industry. In this paper my endeavour will be to locate Acharya Prafulla Chandra, not only as a scientist but also as an industrialist, a social thinker, an educationist and a cultural theorist who played a significant role in the social reformation, moral regeneration, economic development and political emancipation of India. In scrutinizing the corpus of Ray's writings on science, industry and society, I shall try to trace a consistent postcolonial strain in Ray that used the tools of mimicry and imitation to challenge the colonial apparatus.
\end{abstract}

Keywords: Nationalism, Postcoloniality, Acharya Prafulla Chandra Ray.

I can assure you, however, dear sister, that in serving my favourite science I have only one idea in my mind, namely, that through her I should serve my country. Our aspirations are the same. God knows, I have no other object in my life. (Ray, 1932 \& 1935, p. 233)

In the late nineteenth and early twentieth century, India witnessed a steady progress and development of science, which was largely inspired by the British colonial expansion and its imperial practices. The deployment of science by the British as a facilitator of colonial rule generated a corresponding interest in science among the Western educated indigenous intelligentsia. These intellectuals and scientists sought to cultivate and utilize the knowledge of science and technology in constructing the concept of nationhood and to challenge the colonial apparatus. Among these leading scientists of India, Acharya Prafulla Chandra Ray (1861-1944) was one of the most important figures. Challenging the Western hegemony over science and rationality, Ray conceived of science and its practices as a universal phenomenon and claimed India's active participation in the enterprise of modern science, which would eventually serve as an effective weapon against colonialism.

This chapter has attempted to trace a consistent postcolonial strain in the vast corpus 
of Prafulla Chandra Ray's writings. It argues how using the colonial discourses of science and rationality, Ray attempted to create an empowered space of hybridity through which he questioned the colonial authority.

The rise of science in Europe in the eighteenth century coincided with the Western project of colonial expansion. The rapid advancement of technology in the aftermath of the Industrial Revolution - the discoveries of steamships, railways, electric telegraphs - all started to be utilized for the European imperial practices. The Western colonial territories, in this respect, appeared to be the appropriate testing grounds for a host of experiments in the application of science and technology by the colonial state. Europe's rejuvenated interest to obtain the knowledge of science and technologies in this sense was enmeshed with a discourse of power, with its interest to acquire, control and understand the vast tracts of alien territory.

Deepak Kumar has argued that survey and expansion went hand in hand with the early English settlers in the colony:

Every boat that touched the Indian shores had a medical man on board. Trained in the scientific seminaries of Scotland and Northern Europe, he would be known as surgeon-naturalist: and true to his training, in his spare time, he would look for and report on the topography, minerals, flora, fauna and people of his area. They were scientific soldiers who willingly and promptly extended the help of 'new' knowledge to the process of colonial expansion and consolidation. (Kumar, 2007, p. 96)

The reputed historian of science, George Basalla proposed a three-stage model to account for the origin and development of Western science in the non-European colonial countries. Basalla's model proposes a universal pattern of the diffusion of Western science, cutting across geographical, cultural and other differences among the non-European societies. It points to the growth and evolution of the Western scientific knowledge to the colonial territories from the stages of exploration to dependence and then to independence (Dasgupta, 2007, p. 326). Scholars of the history of science have been more or less unanimous in their opinion to define the cultural encounter of India and Britain as a journey from an uneasy acceptance, to a quest for identity and finally to the sowing of the seeds of decolonization.

Though deployed by the British with an imperialistic agenda, the very discourse of science nevertheless created a strong interest among the colonized. Science with its metaphor of modernity and progress appeared before the indigenous population with a sense of awe, so much so that it attained a magical status. In one of his essays, Bankim Chandra Chatterjee marvelled at the vast strides made by science in expanding the knowledge of the universe:

Look at the railways, and the engines which surpassing a hundred thousand of the horses of Indra in strength, make a month's journey in a day. Look at the ships ... The Babu who with a telescope, observes the eclipse of Jupiter's moon, would, if he had been born fifty years earlier, have worshipped Jupiter with offerings of rice, bananas, incense and lamps. (Chatterjee, 1986, p. 7)

It was from the time of Rammohun Roy, that science began to be conceived by the indigenous intelligentsia as a metaphor of modernity and progress and the intellectuals became convinced with the fact that 'to be a nation was to be endowed with science, which had become the touchstone of rationality' (Prakash, 2000, p. 6-7). Partha Chatterjee argues that the very concept science and modernity which had earlier been deployed by the 


\section{Science, a Metaphor of Nationalism: Acharya Prafulla Chandra Ray and Postcoloniality}

colonizers to legitimize the colonial authority had begun to be appropriated and conceptualized by the Indian elites to construct the concept of nationhood. They at once sought to redefine the indigenous traditions and rationalize the society in terms of the modern Western scientific discourse. At the same time by using the same discourse of modernity and rationality they attempted to disrupt the colonial rule and decolonize the nation:

Let us remind ourselves that there was a time when modernity was put forward as the strongest argument in favour of the continued colonial subjection of India: foreign rule was necessary, we were told, because Indians must first become enlightened. And then it was the same logic of modernity which one day led us to the discovery that imperialism was illegitimate; independence was our desired goal. (Chartterjee, 1997, p. 19)

This conceptualization of science as a syntax of reform and modernity, which first originated in the writings of Rammohun Roy had been successfully carried forward by a band of sociocultural reformers, namely, Akshay Kumar Dutta, Keshub Chandra Sen, Iswar Chandra Vidyasagar, Bankim Chandra Chatterjee, Rabindranath Tagore as well as a group of emerging Indian scientists, like Mahendra Lal Sircar, Acharya Jagadish Chandra Bose, Acharya Prafulla Chandra Ray and others. These scientists and intellectuals argued in favour of a valiant Indian nation which could be built with a synthesis of the Indian heritage and the scientific and intellectual vigour of Europe. Thus, in them we can locate the emergence of two critiques - a critique of Western imperialism and an inward critique of indigenous dogma. The debate on science was carried forward in these two directions.

The diffusion of Western scientific knowledge in India and the subsequent response of the Indian intelligentsia to the modern European discourse of science and rationality can be contextualized within the theory of hybridity and mimicry as postulated by Homi Bhabha in Location of Culture (1994). Bhabha locates the question of culture in the realm of the beyond, to a moment of transit. Bhabha writes:

Our existence today is marked by a tenebrous sense of survival, living on the borderlines of the 'present' ... The 'beyond' is neither a new horizon, nor a leaving behind of the past ... but in the fin de siècle, we find ourselves in a moment of transit where space and time cross to produce complex figures of difference and identity, past and present, inside and outside, inclusion and exclusion. (Bhabha, 1994, pp. 1-2)

Interrogating the very concept of a pure, fixed or authentic culture, Bhabha argues that the encounter between the colonizer and the colonized is marked with the production of 'hybrid positioning', a 'third space' which itself questions the binary logic of the colonial discourse:

What is theoretically innovative, and politically crucial, is the need to think beyond narratives of originary and initial subjectivities and to focus on those moments or processes that are produced in the articulation of cultural differences. These inbetween' spaces provide the terrain for elaborating strategies of selfhood - singular or communal - that initiate new signs of identity, and innovative sites of collaboration, and contestation, in the act of defining the idea of society itself. It is in the emergence of the interstices - the overlap and displacement of domains of difference - that the intersubjective and collective experiences of nationness, community interest, or cultural value are negotiated. (Bhabha, 1994, p. 2)

The Indian intellectuals were impressed by the West's conceptualization of science as a tool 
of modernity and progress. Therefore, they appropriated this discourse of science and rationality to fight against the contemporary indigenous malpractices and to enlighten the society. At the same time, by upholding the intellectual heritage of ancient India, they sought to contest the tag of inferiority imposed by Europe upon the East and claimed for India's ability to participate in the world's advancement of knowledge.

It is in the context of this mutual intersection between science, modernity and nationalism that a critical analysis of Acharya Prafulla Chandra Ray's writings becomes relevant. This chapter has attempted to project Ray not merely as a scientist, but at once a historian of science, an industrialist, an entrepreneur and a social critic. To Ray, science was never an end itself, but it was to be integrated with the development of a public use of reason and the emergence of Indian nationalism. Though scholars of the history of science earlier have attempted to trace a distinct nationalist consciousness in Prafulla Chandra Ray's scientific writings, there we cannot locate any other attempt to situate and study Ray's writings within a critical, theoretical framework. This is precisely the space which this chapter has attempted to explore.

As an early document of Prafulla Chandra Ray's postcolonial and nationalist self assertion, it is important to mention his essay, "India Before and After the Mutiny", which Ray wrote for an essay competition in 1885, while he was studying at the University of Edinburgh. The relevance of this essay lies in its understanding of the dialectic between acceptance and resistance which forever remained present in Ray's approach to the West. In the essay, we can locate Ray's strong anti-colonial and nationalist sentiment in which he unsparingly criticized the selfish, harsh and cruel exigencies of the British colonial policy that was discriminatory towards the Indians. Ray remarked - "The lamentable condition of India at present is due to England's culpable neglect of, and gross apathy to, the affairs of that empire. England has hitherto failed - grievously failed - in the discharge of her sacred duties to India" (Ray, 1991, p. I).

Ray's study of the ancient Indian scientific practices had eventually informed his writings and researches on modern Indian chemistry. In fact, by bringing into light a glorious Indian scientific heritage, Ray's attempt was to claim for India's equal share in the world's advancement of modern science. Countering the stereotypical image of the Orient as 'essentially spiritual', Ray in his History of Hindu Chemistry sought to question some of the essentialized concepts about the East and the West in Orientalist literature and undertook a historical analysis of the scientific past of India, thereby attempting to trace a rich tradition of classical Indian Chemistry. Ray refuted and critiqued the Orientalist narrative of the origin and progress of Chemistry, which completely disregarded the existence of any scientific heritage in India. Among these, Marcelin Berthelot's L' Alchimistes Grecs (History of Greek Alchemy), published in 1885, proved to be the most influential one. The central thesis of Berthelot's work was concerned with the origins of alchemy in ancient Greece and its diffusion in the Mediterranean basin, and subsequently to the Orient (Raina, 1997, p. 16). Ray posed his work against Berthelot's thesis to argue that India, like Greece, too had an independent, indigenous and parallel history of Chemistry from its antiquity (Chakrabarti, 2004, p. 230).

Ray's approach to the West and his reading of the Orientalist account of the history of Chemistry in this respect can be analyzed in terms of the complex mechanism of mimicry that Homi Bhabha has elaborated in his Location of Culture. In spite of the positive inspirations that Ray received from the noted European scholars and his deep reverence towards these savants of Chemistry, his stance was not one of blind emulation, but of critical 


\section{Science, a Metaphor of Nationalism: Acharya Prafulla Chandra Ray and Postcoloniality}

examination and analysis.

Living in an era when scientific progress had become the great denominator of nationhood, 'Ray was convinced that a nation needed its own rational tradition, particularly in science' (Chakrabarti, 2004, p. 220). In addition to contest the Western hegemony over science and rationality, one of the primary aims of Ray's writing the History of Hindu Chemistry was to rejuvenate the colonized psyche. Ray firmly believed that the confirmation of an ancient glorious past would surely stimulate the people to regain their true self- "The Hindu nation with its glorious past and vast, latent potentialities may yet look forward to a still more glorious future, and, if the perusal of these pages will have the effect of stimulating my countrymen to strive to regain their old position in the intellectual hierarchy of nations, I shall not have laboured in vain" (Ray, 1932 \& 1935, p. 164).

In an endeavour to find independent Indian roots in the field Chemistry, Ray in his book, started with a discussion on the alchemical ideas of the 'Vedas' and moved on to the periods of the Charaka and the Susruta, which was called the 'Ayurvedic Period.' Then he talked about the pre-Tantric period from 800 A.D. to 1100 A.D., when Buddhist influences were felt on Indian medicinal practices. The Tantric Period was from 1100 A.D. to 1300 A.D., when mercury was used for medicinal purposes. This art, Ray argued, found its fullest development in the Iatro-Chemical period during 1300-1600 A.D., the time of the great Buddhist scholar Nagarjuna and the great Tantric texts like Rasendrachintamani and Rasaratnasamuchchaya.

In writing the history of a vibrant Hindu scientific heritage, Ray simultaneously attempted to draw a parallel scientific history of Greece, vis-à-vis the Europe. Ray argued that in the West, science originated and developed from its own history of occultism and mysticism, like that in the East. Thus, dismissing the claims of superiority posed by the West, which always sought to make a rigid binary distinction between a spiritual East and a materialist West, Ray strongly asserted that the West too had its spiritual and mystic past like that of the East. This attempt of Ray to write a parallel scientific history of Greece and India was to question the pre-conceived notion of the West that categorized the East as inherently spiritual and projected itself as essentially rational and materialist. At the same time, through this reversal of the character of the Orient and the Occident, Ray was also perhaps trying to propose a civilizational synthesis and the universality of science (Chakrabarti, 2004, p. 222).

Prafulla Chandra Ray's account of the history of Hindu Chemistry ends with his narrative of the decline of this glorious Indian scientific spirit from about sixteenth century onwards. Ray linked this deterioration of the rich scientific temper with the emergence of the growing caste rigidities in contemporary Indian society. With the steady decline of Buddhism and the rise of Brahminism, the caste system was firmly established in India in a more rigid form. The Manusmriti, and later the Puranas tended to glorify the priestly class. This class, though traditionally recognized as the carrier of the cult of rationality and science, now stopped being intellectually active.

This approach of Ray to locate the reason of the Indian scientific decline within its own socio-cultural matrix has been identified by Dhruv Raina as the 'inauguration of the social history of science' (Raina, 1997, p. 14). Raina argues that whereas the Orientalist literature on India has always tended to decontextualize the Indian knowledge from its social matrix, Ray's analysis of the caste issue has located the problem both beyond the East-West discourse as well as the nature of scientific practice in India. 
Acharya Prafulla Chandra Ray's Hindu Chemistry vis-à-vis his writings on science reveal a consistent postcolonial outlook. On the one hand, Ray persistently resisted the West's stereotyping of India as medieval by drawing attention to its scientific past; while simultaneously he also praised and appreciated the West's unflinching dedication towards the cultivation of knowledge and in contrast critiqued the Indian society which had plunged itself into the darkness of social rigidities and prejudices since the Brahminical revival against Buddhism. From this perspective it can be said that, Prafulla Chandra Ray's idea of nationalism does not represent an exclusivist ideology. Unlike the Orientalist discourse, which sought to project the superiority of the 'self' by demeaning the 'other', Ray's postcoloniality embodies a cross-cultural mentality, a cosmopolitan outlook, who depicted the West not as an enemy to the East or its binary opposite, but rather complementary to each other.

Acharya Prafulla Chandra Ray's thrust was not for science per se, for he conceived science as part of a project of nation building. A teacher at the Presidency College, Calcutta, Ray through a talented band of his students created an Indian school of chemistry and made his life-long advocation for the dissemination of modern scientific research and education in the country. In this context, it is significant to note Ray's critique of the negligence on the part of the colonial government in the spread scientific education in India, and simultaneously his attack on the prevalent education system, which instead of generating interest in pursuing original scientific research among the students, fostered an insane craze to acquire university degrees. Ray never wished science and research to be confined within their pedagogic realm, which, to him, must have their applicability for the need of the society. Thus, Ray conceived the growth of industries as a key to the economic independence of India, for which the Bengal Chemical stood as a perfect model.

The first most effective and practical effort to institutionalize Indian interest in Western science was Mahendra Lal Sircar's Indian Association for the Cultivation of Science in 1876 from which Ray took a lot of inspiration. Sircar argued against the prevailing contention that the Hindu mind was metaphysical, and called for the cultivation of the sciences by 'original' research, to be conducted in purely national terms. The other notable indigenous institutions with aimed to promote scientific education in India and with which Ray was in some way or other, directly or indirectly associated were the Dawn Society (1902), the National Council of Education (1906), the University College of Science (1915), the Bose Research Institute (1917), the Indian Science Congress Association (1924), the Indian Academy of Science (1934), and the National Institute of Science (1935).

As a modern scientist, Ray realized the need for advanced laboratories and institutions having all the required facilities which would be conducive to higher scientific researches. Along with Sir Alexander Pedler, Ray took initiatives to modernize the Presidency College laboratory. His continuous and active contacts with Europe and his regular visits to the various countries of the continent had given him the opportunity to remain in tune with the latest advancements of modern scientific researches, which he always sought to emulate and apply for the scientific and intellectual progress of his nation. Ray thus looked at the modern West as a source of inspiration and encouragement to the Indians who should never hesitate to learn and appropriate the new discoveries and researches made by the West in the fields of science and technology.

While at Presidency College, Ray as a teacher and disseminator of science, always inspired his students to pursue original and higher scientific researches and infused within them the very spirit of curiosity and enquiry what he found in the West. For Ray, the 


\section{Science, a Metaphor of Nationalism: Acharya Prafulla Chandra Ray and Postcoloniality}

Presidency College was a realization of one of the long-awaited dreams of his life, where he sought to establish a School of Chemistry of his own by a dedicated band of his pupils, namely, Jnanendra Chandra Ghosh, Jnanendra Nath Mukherjee, Maniklal Dey, Satyendra Nath Bose, Pulin Behari Sarkar, Rasik Lall Datta, Nilratan Dhar and Megh Nad Saha. Ray had always had a long-cherished dream to conceive of India a scientifically developed nation, which had once been the cradle of rationality and progress. By forming a School of Chemistry through his pupils, which could boast to have its unique Indian identity, Ray wished his nation to claim its own share in the world's advancement of modern science and to remove the badge of inferiority stamped upon it by the West.

Pointing out the several factors, which had been detrimental to the furtherance of the scientific education in India, Ray not only accused the indigenous people and their indifference towards the cultivation of rationality and intellect, but also held the contemporary colonial government responsible for not being adequately supportive. Though Ray considered the colonial rule in India as a blessing in disguise through which the latter could come into contact with the modern Western scientific and technological advancements, he was nevertheless harshly critical about the biased and selfish pursuit of the colonial policy that was discriminatory towards the Indians. Ray was particularly critical about the virtual ostracism of the Indians from most of the higher responsible posts in the various scientific services of the government. Ray had high expectations and a deep faith towards the capability of the Indians to match the talents of the European scholars of repute. Ray's creation of an Indian School of Chemistry, in this respect, served to fulfill two crucial purposes. It was at once a reply to the colonial government's negligence towards the indigenous talents and merits; while at the same time, it was also an effort to popularize science amongst the masses and to instill a fresh confidence in the colonized psyche of India's capability to participate in the modern scientific studies.

In spite of his admiration for Europe's scientific and technological advancement, Ray unsparingly critiqued the ruthless economic exploitation of the British colonizers in India that consequently led to a severe financial exploitation during the colonial period. As an ardent nationalist, Ray actively participated in the programme of swadeshi that aimed towards a scientific and economic self-reliance. Ray's concept of the postcolonial nation, from this perspective, was fundamentally laid in the economic liberation or swaraj from the Western colonial hegemony in which science was to play a crucial role. Ray realized that the true dissemination of science would lay in its application in industry and technology which could eventually stabilize the economic condition of a nation. Hence, Ray's repeated urge for the pursuit of original scientific researches was not devoid of the material reality of the contemporary society but rather was ingrained within it.

Interestingly, Ray looked at the West as an ideal model to follow where scientific education and industrialization had progressed on an equal footing - "In Europe industry and scientific pursuits have gone hand in hand, both have advanced pari passu, the one helping the other - in fact, industry has, as a rule, preceded science, though based upon empirical knowledge ... No doubt science comes in as a ready handmaid to industry" (Ray, 1932 \& 1935, p. 92). Through his experiences and his in-depth study of the material resources of the country, Ray was not slow to realize that India had a bright future in the industrial and business concerns which could one day liberate the nation from its economic deprivation and the foreign colonial domination. Therefore, Ray's stance was to imbibe the Western knowledge of science and technology, but to deploy it for nation building and consequently to overthrow the colonial regime. 
Ray began his endeavour with the manufacturing of copperas or sulphate of iron (made from scrap iron and sulphuric acid) of which he found a demand in the local market of Calcutta. Gradually his manufactured chemicals included - carbonate of soda, phosphate of soda (prepared with bone ashes, sulphuric acid and soda), super phosphate of lime and etc. During this time Ray had already begun to devote his time to the study of the Hindu medicinal practices in the Ayurvedic and Tantric periods. By 1888, he was glancing over Indian materia medica. After carefully studied Udoychand Dutt's Materia Medica of the Hindus and Kanai Lal Dey's Indigenous Drugs of India, Ray, primarily with the initiative of Amulya Charan Bose, who 'had an instinctive liking for and faith in the therapeutic properties of the indigenous drugs used by our Kavirajas', commenced preparations of Kalmegh (Andrographis paniculata), Kurchi (Holarrhena antidysenterica), syrup of Vasaka (Adhatoda Vasica) and Aqua Ptychotis (Ajowan water) according to the scientifically up-todate methods (Ray, 1932 \& 1935, pp. 104-05 \& Raina, 1997, p. 61).

With the dedicated co-operation of his associates, Ray's long-cherished dream of establishing an indigenous chemical and pharmaceutical industry was finally materialized. Ray named it, the Bengal Chemical and Pharmaceutical Works. Though the initial works of the institution had already begun from the year 1892, it is on April 12, 1901, that the Bengal Chemical attained the recognition of a limited liability company and started its business at 91 Upper Circular Road, Calcutta. Ray's motto behind the establishment of the company was at once to stop the Western economic exploitation in India and simultaneously to encourage the indigenous people to take up industrial and business enterprises, which would eventually bring the economic self-reliance to the country.

However, regarding India's poor progress in trade and commerce, Ray never held the colonial government solely responsible for its unsympathetic attitude towards the subject race. He also accused the slothful attitude of Indians towards the country's industrial and business concerns. Ray particularly critiqued the excessive inclination of the Indian youth to seek a clerical job without thinking for better career options in entrepreneurship. Ray launched his bitter diatribe especially against the apathy of the Bengalis in pursuing a career in business, as he wrote- "The Bengali is now believed to have an instinctive aversion to mercantile enterprises, and to sea-voyages. But historical records are available to prove that he bore a conspicuous part in the external and internal trade of the land of his birth" (Ray, $1932 \& 1935$, p. 347).

From this perspective, the Bengal Chemical and Pharmaceutical Works of Ray was not only an attempt to prevent the economic exploitation of the British colonial government in India, but it was in itself a reply to the slothful and indolent attitude of the Bengalis, as Ray wanted the institution to become a model of inspiration and encouragement to the youths. On the other hand, Ray's formation of an Indian School of Chemistry became a testimony to the capability of Indians to participate in the modern scientific discourses, through which he challenged the stigma of inferiority imposed by the West on the East.

As a scientist, Ray never took part in militant Indian political freedom movements or agitations. However, as a nationalist, he could never keep himself aloof from his nation's political struggle for independence. Ray's baptism in active politics came through his contact with, first, Gokhale and then Gandhi. In spite of being an ardent advocate of modern science himself, Ray readily espoused and propagated Mahatma Gandhi's philosophy of the charka (the spinning wheel) and khadi, which were potent nationalist symbols of the contemporary society. 


\section{Science, a Metaphor of Nationalism: Acharya Prafulla Chandra Ray and Postcoloniality}

As a modern scientist, Ray recurrently urged for the development of industries and mechanization that could lead to the economic progress of a nation. However, he actively took part in Mahatma Gandhi's programme of charka or hand-spinning, as he conceived it to be a means of eradicating poverty and unemployment. Gandhi's programme of producing yarn by domestic hand-spinning was to Ray a means of small-scale employment to the poor peasants of rural India. This, Ray believed, could remove their economic distress and could consequently help in the generation of national wealth that was otherwise being wasted in the import of expensive foreign clothes. At the height of the Non-cooperation Movement, Ray proudly announced - "Science can afford to wait but Swaraj cannot (Ray, 1932 \& 1935, p. 228).

Having firmly rooted his faith in the Gandhian notion of asceticism and his moral and ethical principles, Acharya Prafulla Chandra Ray was nevertheless apprehensive of 'a new kind of imperialism', brought forth by the tremendous scientific and industrial advancement, threatening man's moral progress and the very ethics of humanity. Prafulla Chandra Ray's critique of the steady degeneration of the moral principles within a man was perhaps largely prompted by his disillusionment over the despotic and brutish colonial rule in India. Out of the hunger for power and material prosperity and driven by the very instinct of domination and exploitation, the British rulers in India had applied every means to ruin the subject race in every sphere of life - political, economic or social. Ray's critique of British imperialism thus suggests that being a modern scientist though Ray recurrently emphasized the need to emulate the Western advancement of science and rationality, he never adhered to the Western capitalist spirit that sought to acquire wealth and material prosperity at the cost of humanity. This very principle of morality and ethics is also found reflected in Rabindranath Tagore's discourse of science and modernity, who in spite of his many debates and disputes with Gandhi and Ray, in terms of their nationalist programmes of charka and khadi, however, shared an equal ground in respect to his critique of the excessive acquisitive and materialistic instinct of the West.

Acharya Prafulla Chandra Ray's deep rooted concern for the poverty and economic distress of colonial India, especially the contemporary Bengal also led him to think about the food habits and dietary practices of the indigenous masses. In this respect, Ray's primer on food, Khadya Bigyan (The Science of Food, 1936) can be located as part of his nationalist project of devising ideal diets for the Bengali individual. It would be worthwhile to note that a substantial corpus of Ray's writings discussed dietary practices as sources of preventive and curative medicine in the context of Bengali health in the early twentieth century. A key text in this analysis is his short essay, "Chira, Muri, Khoi, Biscuit" where diets like Chira, Muri and Khoi (varieties of beaten and puffed rice) were seen as rich sources of carbohydrates that were easily affordable to the Bengali individual.

Prafulla Chandra Ray's point was that a return to and a respect of traditional dietary practices might prevent and cure numerous diseases, like malaria, tuberculosis and dyspepsia. Ray's critique of the adoption of English food was intricately linked with the issue of colonial exploitation. The two sharpest targets were tea and biscuit. Ray's writings on tea drew upon tea as lacking food value and initiating diseases like insomnia, dyspepsia and others. Ray realized the fact that the attempt of the colonial government to project tea as a source of health was actually an attempt to trap and economically exploit the indigenous population.

A substantial portion of Prafulla Chandra Ray's criticism of the English colonial rule embodies his fierce diatribe against the 'divide and rule' policy of the colonial government, which by setting one class against another sought to perpetuate the very seeds of dissension 
among the masses, thus making it almost impossible for India 'to rise again as a nation'. Ray was particularly critical about the factions created by the British rulers between the Hindus and the Muslims, as the communal disharmony between these two religious sects was to serve as a potential tool of imperialism. One of the policies of the colonial government to justify its rule and to maintain its status quo was to circulate the inestimable boon theory among the colonized. Fabricating a different history of the pre-colonial India, the foreign rulers circulated the idea that their rule, as if appearing as a 'Godsend', had actually rescued the masses from the age-long oppression and rapacity of the Muslim rulers (Ray, 1932 \& 1935, p. 241). Countering this narrative of the British imperial discourse, Ray went on to give an authentic portrayal of the Muslim rule in the pre-colonial era, where the very notion of communalism was actually found absent.

Ray's comparative study of India under the British rule and that under the Mogul dynasty served as an effective weapon to critique the hegemonic rule of the colonial government, which, unlike the Muslim rule, was discriminatory towards the Indians. The very notion of communalism which was alien in the pre-colonial India was actually manufactured and exploited by the British for their own political ends. In response to the British rulers' attempt in implanting the very seeds of dissension among the Indians, Ray made an interesting analogy between the political and cultural history of Europe with that of India, through which he held the latter superior in terms of its spirit of toleration and its religious and communal harmony. The history of Europe, Ray analyzed, was replete with violent wars, political unrest and religious intolerance. This comparative analysis between the socio-cultural histories of India with that of Europe served to fulfill two crucial purposes in Prafulla Chandra's nationalist discourse - firstly, to restore the very spirit of unity and solidarity among the indigenous masses, which the colonial rulers was attempting to exploit for their own imperial agenda; and secondly, to refute and question the claims of Western racial and cultural superiority, which had always attempted to project the Indians as a race of primitive, savage and brutish origin.

However, Ray's critique of India's failure to progress as a modern civilized nation was not exclusively directed towards the exploitative and hegemonic rule of the British colonial government. He simultaneously depicted the class and caste rigidities of India, especially that of Bengal, 'a stumbling block' to the growth of nationalism:

The division of the Bengali society into numerous sects and sub-sects - the Varendra, Rari, Vangaj, etc. - is the logical outcome of the ill-fated Kulinism. Standing on the threshold of the $20^{\text {th }}$ century we can now take a survey of the multitude of evils wrought by this system ... The Bengali people thus ceased to be a nation having community of interests, but was split up into a congeries of sects and classes. (Ray, 1918, pp. 195-96).

Acharya Prafulla Chandra Ray's social writings, in this sense, are marked with a complex nationalist perspective. On the one hand, Ray was unsparing in his criticism of the selfish and retrograde British colonial rule that sought to exploit India for its own imperial aggrandizement; on the other hand, Ray was trenchantly self-critical towards the class and caste prejudices of the contemporary Indian society, as well as the lack of perseverance and blind ignorance of the masses at large, which had been equally responsible for posing hindrances towards India's progress as a nation.

Through a detailed critical analysis of the writings of Acharya Prafulla Chandra Ray, this chapter has attempted to locate the various facets of his postcoloniality. Science to Ray 
was never an end in itself, but rather was conceptualized by him as part of a broader cultural discourse. In the context of the emerging nationalist discourse of the nineteenth century colonial India, Prafulla Chandra Ray conceived science to be an instrument of nation building.

\section{References}

Bhabha, Homi K. (1994). The Location of Culture. Routledge.

Chakrabarti, Pratik. (2004). Western Science in Modern India. Permanent Black.

Chatterjee, Bankim Chandra. (1986). Sociological Essays: Utilitarianism and Positivism in

Bengal. Trans and Eds. S. N. Mukherjee and Marian Maddern. Ridhi India.

Chatterjee, Partha. (1997). Our Modernity. SEPHIS.

Dasgupta, Subrata. (2007). Response to Western Science: Failures and Successes. In S. Irfan Habib and Dhruv Raina (Eds.), Social History of Science in Colonial India (pp. 326-

51) Oxford University Press.

Kumar, Deepak. (2007). Colony and Science: A study of British India. In Jyoti Bhusan Das Gupta (Ed.), Science, Technology, Imperialism and War. Gen. Ed. D. P.

Chattopadhyaya. History of Science, Philosophy and Culture in Indian Civilization

(Vol. XV. Part. 1. pp. 89-119). Pearson Longman.

Lourdusamy, J. (2004). Science and National Consciousness in Bengal (1870-1930). Orient

Longman Private Limited.

Prakash, Gyan. (2000). Another Reason: Science and the Imagination of Modern India.

Oxford University Press.

Raina, Dhruv. (1997). The Young P.C. Ray and the Inauguration of the Social History of

Science in India 1885-1907. Science, Technology Society 2(1), 2-40.

Ray, Acharya Prafulla Chandra. (2001). Chira, Muri, Khoi, Biscuit. In Syamal Chakrabarti

(Ed.), Acharya Prafulla Chandrer Prabandha (pp.69-75). Kolkata: Aajkaal.

---. (1918). Essays and Discourses. G. A. Nateson \& Co.

---. (2008). Khadya Bigyan. In Anil Bhattacharya (Ed.) Acharya Prafulla Chandra Ray

Rachana Sankalan (Vol. 1, pp. 310-503). Kolkata: Acharya Prafulla Chandra College.

---. (1903 and 1909). A History of Hindu Chemistry. (2 vols). Calcutta: The Bengal Chemical

\& Pharmaceutical Works Limited.

---. (1991). India Before and After the Mutiny. Acharya Prafulla Chandra Sammilanee.

---. (1932 and 1935). Life and Experiences of a Bengali Chemist. (2 vols). Chuckervertty,

Chatterjee \& Co.

---. (2003). The Shakespearean Puzzle-Endeavours after its Solution. Ed. Pinak Pani Dutta.

Acharya Prafulla Chandra Sammilanee.

Said, Edward W. (1995). Orientalism. Penguin Books.

\section{$\underline{\text { Bio-note }}$}

Dr. Biswanath Banerjee is an Assistant Professor of English at Rammohan College (University of Calcutta), Kolkata. He completed his doctoral studies from the Department of English, Visva-Bharati on the Writings of Acharya Prafulla Chandra Ray under the supervision of Prof. Amrit Sen. Dr. Banerjee has long teaching experience of ten years. Dr. Banerjee had been nominated and worked as a Fellow of the UGC-UKIERI Project 
coordinated jointly by Edinburgh Napier University, Scotland and Visva-Bharati, Santiniketan, India in 2014-2016 (under the supervision of Prof. Bashabi Fraser, Prof. Tapati Mukherjee and Prof. Amrit Sen). Dr. Banerjee had also been associated with several research projects in Visva-Bharati. He had also been associated with the editorial board of The VisvaBharati Quarterly (the multi-disciplinary, peer- reviewed journal) and had assisted as a proof reader and copy editor in different publications of Visva-Bharati. His research interests include Postcolonial studies, Tagore studies, partition literature, late nineteenth and early twentieth century Indian English writing, Bengal Renaissance and history of science.

Email Id: biswanathbanerjee84@gmail.com 